\title{
Parental Involvement in Improving Independence in Early Childhood
}

\author{
Mukti Amini \\ Early Childhood Education Program \\ Universitas Terbuka (UT) \\ Jakarta \\ muktiamini@ecampus.ut.ac.id
}

\begin{abstract}
The purpose of this study is to see the involvement of parents of early childhood in familiarizing children to take care of themselves during at home. The method used in this research is explorative study with descriptive analysis. The research was conducted in February of 2016. The research place was in South Tangerang, Indonesia. The research subjects were 30 mothers of children with 5-6 years old who joined in Pos PAUD. The results show that in general parental involvement in improving children's independence is good enough but still needs to be improved in terms of training children to eat without feeding, making simple food and drink, and clean up the cutlery. Therefore the Pos PAUD as non-formal institution of early childhood education needs to think about the appropriate engagement strategy for parental involvement during at home is more optimal.
\end{abstract}

Keywords-parental involvement; independence; early childhood

\section{INTRODUCTION}

Early childhood education can take place informally, formally, and non-formally. Informally, children are educated by their parents at home. Formally, children's education can take place in kindergartens. Being non-formal, education can take place in various institutions, for example: in daycare, play group, posyandu, and so on. One of the non-formal education institutions is 'Pos PAUD' or Early Childhood Education post, which is usually established independently in each village or district. The ages of children educated at Pos PAUD vary, from ages 3 to 6 . At Pos PAUD, various aspects of child development are given stimulation in order to achieve optimal development.

One aspect of development that is very necessary to be developed in early childhood is the aspect of independence. James stated that in education, we must make automatic and habitual, as early as possible, as many useful actions as we can, and guard against the growing into ways that are likely to be disadvantageous to us [1]. Independence is one of the things that need to be developed through habituation. Because everyday children are with family or teacher at PAUD post, it is necessary to align to train independence both at home and in the early childhood institution. This is in line with Ferara\&Ferara' stated that parental involvement is essential to support the learning of children, both in formal schools and in learning courses[2].

Besides that, parents have an influence to the child's attention, values, learning, concepts, emotions and ideas. They have a right within affect children's education[3]. Therefore, parent involvement plays an important role in developing their child independence. Especially most of the time a child in a day is with his parents.

However, many found that children educated by parents at home do not run in harmony compared than conducted at PAUD institutions. One such discrepancy is in the development of independence in children. Problems sometimes occur in the parents, sometimes in Pos PAUD institutions. Therefore, this study aims to see the involvement of parents in training children's independence to familiarize their self-helped during at home, especially in terms of eating and drinking without being assisted.

Parental involvement. Parental involvement can be defined as an attempt to increase parental participation in education and experience for their children[4]. While Hill \& Taylor stated that parental involvement includes: maintaining the child's progress, communicating with teachers, ensuring that children enjoy challenges, good learning classes, and directing children to have high achievement motivation in school[5]. Epstein stated that one type of parental involvement that is learning at home. It means that involve families with their children inacademic learning at home, including homework, goal setting, and other curriculum-related activities[6]. While the PAUD institutions support learning at home activities that strengthen the school curriculum by providing various strategies for parents to help children learn at home.

Independence. According to Erikson, child independence can be defined as an attempt to escape from the parents in order to free them by the process of seeking the identity of the ego that is the development toward a stable individuality for self-sufficiency[7]. In children aged 5-6 years, independence of children in taking care of itself should have been formed because the child will begin to enter elementary school. In detail based on various theories of child development, child independence consists of several dimensions: maintaining cleanliness and neatness, cleaning up his possessions[8], eating and drinking himself properly without being helped[9], and wearing clothes and shoes without help. This study 
focuses on the independence of children in eating and drinking themselves properly without being assisted.

\section{METHOD}

The method used in this research is explorative study. This method is used to get the description of the condition of research subjects. The subjects were 30 mothers of children aged 5-6 years, who studied at Pos PAUD Amanah, South Tangerang, Banten, Indonesia. The study was conducted in February 2016. This study uses a questionnaire about parental involvement that has been done at home with the guidance to train children's independence in eating and drinking themselves without being assisted. The instrument consists of 9 items of closed questions using a Likert scale. Validity test was done in two ways that was the validity of the content and the validity of the items. Data obtained in the field are presented descriptively and qualitative analysis.

\section{RESULT AND DISCUSSION}

Based on the result it is seen that in general, parents have been involved well in training the independence of children to be able to eat and drink themselves. But there is parental involvement that still needs to be improved in terms of: not feeding the child while eating, training the children to make their own simple food and drink, and train the children to clean the cutlery. Parental involvement in training children to be able to feed themselves is important. This is because children begin to know how to eat / drink from home with parents. If parents consistently familiarize children to eat properly gradually from an early age, the child will be able to eat properly. It is consistent with the research of which stated that parents powerfully shape children's early experiences with food and eating, providing both genes and environments for children[10]. Children's eating patterns develop in the early social interactions surrounding feeding. These findings suggest a number of potential early intervention approaches that could be used during infancy and very early childhood.

The parental involvement program is one of the standards set out in the early childhood program by NAEYC (National Association for the Education of Young Children), which has been required: the program establishes and maintains collaborative relationships with each child's family to foster children's development in all settings. These relationships are sensitive to family composition, language, and culture [11].

According to Golan \&Weizman, families are typically children's first significant models of eating behavior[12]. Therefore, poor role models influence children's perceptions of foods and mealtimes[13]. For example, negative comments about the taste or texture of a food will make a child less willing to try it. On the other hand, a child is more likely to try a food if he/she observes an adult enjoying it.

Associated with the role of parents in eating habits, then parents are also in charge of helping children develop healthy eating habits. Some respondents stated that while at home, for children to eat without being assisted so the child is left to eat while watching television. Even though according to Brooks, stop eating habits while watching television is important because it encourages the child's desire to eat high-calorie foods and fat snacks[14]. Children who reduce their eating habits while watching television will be better able to control their weight gain. In addition, for the child to eat without assisted, parents need to prepare a table and chairs that fit the child's size and are made of lightweight material that is easy to carry and move[15].

The ability of children is able to eat and drink without being assisted need to continue to be familiarized by parents. According to Montessori, children have a natural desire to learn and work together with their desire to get pleasure. Unfortunately, parents sometimes under estimated with the ability of children. As in the case of clearing the cutlery and making simple meals, parents are just too eager to do everything for their children. In fact, if parents want to spend time for children to practice, then the results will be satisfactory both for children and for parents. So, parents need to suppress the temptation to always want to 'help' the child if parents care about their future[16].

The description of the parents' involvement above in training the independence of their children at home also indicates that PAUD institute really needs to design parenting program that can help the parents to be able to stimulate the development of child independence optimally. According to the standards of NRCHS, parents should be informed of the range of nutrition learning activities[17]. Formal nutrition information and education programs should be conducted at least twice a year under the guidance of the nutritionist based on a needs assessment for nutrition information and education as perceived by families and staff. In addition, the NRCHS organization also recommended that informal programs should be implemented during the "teachable moments" throughout the year. So, the habituation of independence by parents at home is also the progress must always be monitored also by early childhood institutions.

Parental involvement conducted at home is also recommended by Fajarwati who stated that practical life exercises other than can be done at school can also be done by parents at home, because children' time in a day are more at home than in school[17]. The habituation of practical life is very good if done as early as possible

\section{CONCLUSION}

Parental involvement in training child independence is needed. One form of training in independence is to train children to take care of themselves in eating and drinking without being helped. This study illustrates that most parents are good enough to train children's independence in terms of: washing hands before eating, cleaning up food that is falling, eating with no splatter, drinking from glasses without helped, pouring beverages from a pot to a glass without spilling, carrying a cup of drink without spill; but still lack the training of children in the case of: no feeding the children while eating, making their own simple food and drink, and cleaning up the cutlery. Therefore, these shortcomings can be overcome by awareness efforts to parents by PAUD institutions.

\section{References}

[1] W. James, "Pragmatism, a New Name for Some Old Ways of Thinking, Popular Lectures,” 1907.

[2] M. M. Ferrara and P. J. Ferrar, "Parents as partners: Raising awareness as a teacher preparation program," Clear. House A J. Educ. Strateg. issues ideas, vol. 79, no. 2, pp. 77-82, 2005.

[3] R. Maryana and Y. Rachmawati, Pengelolaan lingkungan belajar. 
Prenada Media, 2013.

[4] G. Hornby, Parental involvement in childhood education: Building effective school-family partnerships. Springer Science \& Business Media, 2011.

[5] L. E. Berk, "chap. 10 Emotional Development Child Development p 428-429 Boston." Pearson Publishing, 2006.

[6] J. L. Epstein, M. G. Sanders, B. S. Simon, K. C. Salinas, N. R. Jansorn, and F. L. Van Voorhis, School, family, and community partnerships: Your handbook for action. Corwin Press, 2002.

[7] C.P. Monks, Developmental psychology: introduction in different parts. Yogyakarta: UGM Press, 2006.

[8] P. King and M. Boardman, "What personal/social skills are important for young children commencing kindergarten? Exploring teachers' and parents' insights," Aust. J. Early Child., vol. 31, no. 3, pp. 15-22, 2006.

[9] J. J. Beaty, Observing development of the young child. Merrill Publishing Company, 2009.

[10] J. S. Savage, J. O. Fisher, and L. L. Birch, "Parental influence on eating behavior: conception to adolescence," J. Law, Med. Ethics, vol. 35, no. 1, pp. 22-34, 2007.

[11] S. Ritchie and B. A. Willer, Families and community relationships: A guide to the NAEYC early childhood program standards and related accreditation criteria. National Association for the Education of Young Children (NAEYC), 2005.

[12] M. Golan and A. Weizman, "Familial approach to the treatment of childhood obesity: conceptual model," J. Nutr. Educ., vol. 33, no. 2, pp. 102-107, 2001.

[13] D. Matheson, K. Spranger, and A. Saxe, "Preschool children's perceptions of food and their food experiences," J. Nutr. Educ. Behav., vol. 34, no. 2, pp. 85-92, 2002.

[14] J. Brooks, The Procces of Parenting. New York: Mc Graww Hill, 2011.

[15] E. Hainstock, Teaching Montessori in the home. Random House, 2013.

[16] M. J. Bell, "Caring For Our Children: National Health and Safety Performance Standards: Guidelines for Out-of-Home Child Care Programs," Child. Educ., vol. 70, no. 1, pp. 51-52, 1993.

[17] A. Fajarwati, "Application of Practical Life Exercise 3-4 Years Old,” Sci. J. Vis. PPTK PAUDNI, vol. 10, 2015. 